\title{
RNA and protein synthesis requirements for the resumption of meiosis in rabbit oocytes: the role of cumulus cells
}

\author{
J. Motlík ${ }^{1}$, J. Fulka Jr. ${ }^{2}$, R. Procházka ${ }^{1}$, Z. Rimkevičová ${ }^{1}$, \\ M. Kubelka ${ }^{1}$ and J. Fulka ${ }^{1}$ \\ ${ }^{1}$ Czechoslovak Academy of Sciences, Institute of Animal Physiology and Genetics, Department of \\ Genetics, 277 21Libĕchov; \\ 2 Institute of Animal Production, 104 O0Prague 10, Uhrinèves, Czechoslovakia
}

(3rd Franco-Czechoslovak Meeting, INRA, Jouy-en-Josas, 13-14 December 1988)

\begin{abstract}
Summary - In vitro maturation of rabbit cumulus-enclosed oocytes was fully inhibited in $\alpha$ amanitin- $(100 \mu \mathrm{g} / \mathrm{ml})$ and cycloheximide- $(5 \mu \mathrm{g} / \mathrm{ml})$ supplemented media. The inhibition was reversible and substantially reduced by delaying the addition of $\alpha$-amanitin $(2 \mathrm{~h})$ or cycloheximide $(3 \mathrm{~h}) . \mathrm{In}$ contrast, both drugs did not inhibit germinal vesicle breakdown in denuded oocytes.Co-culture of granulosa cells $\left(1 \times 10^{6} / \mathrm{ml}\right)$ with denuded oocytes did not substitute for an intact cumulus. The data presented here suggest that the resumption of meiosis in rabbit cumulus-enclosed oocytes is dependent upon early transcriptional and translational events which probably occur within the cumulus cells.
\end{abstract}

oocyte maturation - cumulus oophorus - transcription - translation - rabbit

Résumé - Synthèse d'ARN et de protéines nécessaires à la reprise de la méiose : rôle des cellules du cumulus oophorus. La reprise de la méiose in vitro d'ovocytes de lapins inclus dans leur cumulus oophorus est complètement inhibée par l' $\alpha$-amanitine $(100 \mu \mathrm{g} / \mathrm{ml})$ et le cycloheximide (5 $\mu \mathrm{g} / \mathrm{m} /$ ).L'inhibition est réversible et fortement diminuée si l'on retarde le traitement par l' $\alpha$ amanitine $(2 h)$ ou la cycloheximide ( 3 h). Au contraire, les deux inhibiteurs n'empêchent pas la rupture de la vésicule germinale d'ovocytes dénudés (sans cumulus oophorus). Des cellules de la granulosa $\left(10^{6} / \mathrm{ml}\right)$ en coculture avec des ovocytes dénudés ne remplacent pas un cumulus oophorus intact.Les résultats présentés suggèrent que la reprise de la méiose dans des ovocytes de lapins inclus dans le cumulus oophorus est sous la dépendance de phénomènes de transcription et de traduction survenant probablement dans les cellules périovocytaires.

maturation de l'ovocyte - cumulus oophorus - transcription - traduction - lapin 


\section{INTRODUCTION}

Although the spontaneous resumption of meiosis in mammalian oocytes under in vitro conditions was originally observed in rabbits (Pincus \& Enzmann, 1935), the mechanism of oocyte maturation in this species has not been well studied. Only the effects of medium composition, i.e. osmolarity and addition of hormones, have been investigated (Thibault \& Gérard, 1973; Bae \& Foote, 1975a, b; Smith et al.,1978; Magnusson et al.,1981).

On the other hand, in rodent oocytes the effects of cAMP elevating drugs, RNA and protein synthesis inhibitors have been studied extensively (see for review Thibault et al.,1987). Alpha-amanitin, a specific inhibitor of RNA polymerase II involved in the synthesis of hnRNA, does not inhibit the resumption of meiosis in mouse oocytes (Crozet \& Szöllösi, 1980). Sheepdenuded oocytes, cultured in $\alpha$-amanitin supplemented media, also show normal metaphase plates (Osborn \& Moor, 1983). However, the maturation rate of sheep and cattle cumulus-enclosed oocytes is substantially reduced in the presence of $\alpha$-amanitin (Osborn \& Moor, 1983; Hunter \& Moor, 1987).

Protein synthesis inhibitors, i.e. puromycin and cycloheximide, do not prevent the resumption of meiosis in rodent oocytes either; however, the latter cannot proceed beyond the circularly arranged bivalent stage (Schultz \& Wassarman, 1977; Ekholm \& Magnusson, 1979). In contrast, pig, sheep and cattle oocytes - denuded or not - are very sensitive to protein synthesis inhibition (Fulka Jr. et al., 1986; Moor \& Crosby, 1986; Sirard \& First, 1988).

All these studies indicate substantial differences between species in requirements of de novo RNA and protein synthesis for the resumption of meiosis. This study reports the establishment of sensitivity of rabbit oocytes to $\alpha$-amanitin and cycloheximide under in vitro conditions; attention is paid to the site of action of both inhibitors.

\section{MATERIALS AND METHODS}

Pseudopregnancy was induced in 40 sexually mature female rabbits of different breeds with 100 U hCG (Praedyn, Spofa, Czechoslovakia). On the 17th, 18th and 19th day of pseudopregnancy, females were injected twice daily with $0.4 \mathrm{mg}$ of FSH (Folicotropin, Spofa). One day later, the does were killed and oocyte cumufus complexes were isolated under dissection microscope by rupture of the follicular wall of the preovulatory follicles. Oocytes cumulus complexes from 3 does were always pooled.Cumulusenclosed or cumulus-free oocytes (for description of cumulus cell removal, see below) were cultured in $0.1 \mathrm{ml}$-medium droplets under paraffin oil at $38^{\circ} \mathrm{C}$ under $5 \% \mathrm{CO}_{2}$ in air. The culture medium contained : isotonic TC199 (Usol, Prague, Czechoslovakia), $72 \mathrm{mi} ; 1.45 \% \mathrm{NaH}-$ $\mathrm{CO}_{3}+0.002 \%$ phenol red, $18 \mathrm{ml} ; 5.5 \%$ glucose solution, $10 \mathrm{ml}$; sodium pyruvate, $0.004 \mathrm{~g}$; freeze-dried calf serum growth proteins (Usol), $15 \mathrm{mg} / \mathrm{ml}$; penicillin, $50 \mathrm{IU} / \mathrm{ml}$; streptomycin, 5 $\mathrm{mg} / \mathrm{ml}$. The control culture medium was supplemented either with $\alpha$-amanitin at concentrations of 10,50 and $100 \mu \mathrm{g} / \mathrm{ml}$, or cycloheximide (Serva) at concentrations of 1,5 or $10 \mu \mathrm{g} / \mathrm{ml}$. In the first series of experiments, all concentrations of the drugs were tested simultaneously. As 100 $\mu \mathrm{g} / \mathrm{ml}$ of $\alpha$-amanitin and $5 \mu \mathrm{g} / \mathrm{ml}$ of cycloheximide proved optimal for our experimental design, only these concentrations were subsequently used. To test the reversibility of $\alpha$ amanitin and cycloheximide inhibition $4 \mathrm{~h}$ after culturing in the drug, oocytes were thoroughly washed 5 times in the control medium and subsequently cultured in the same medium for another $4 \mathrm{~h}$.

Denuded rabbit oocytes were also cocultured with $1 \times 10^{6}$ parielal granulosa cells $/ \mathrm{ml}$. Granulosa cells from the cavity of preovulatory follicles were obtained by pressing a preparation needle gently against the follicle wall. The 
granulosa cells were pooled and mixed thoroughly by sucking the suspension in and out of a wide-bore pipette. The concentration of the granulosa cells in the suspension containing $0.06 \%$ Trypan blue was determined by counting in a haemocytometer. The cells were then diluted in $\alpha$-amanitin- or cycloheximide-supplemented media to give the desired concentration.

Finally the cumulus cells were removed by hyaluronidase (Hyasa, Sevac) treatment (247 $\mathrm{TRU} / \mathrm{ml}$ ), and the corona radiata by fine pipettes. Denuded oocytes were mounted on slides, fixed in acetic alcohol (1:3 v/v) for $24 \mathrm{~h}$, stained with $1 \%$ orcein and examined under the phase-contrast microscope. Germinal vesicles of freshly-isolated rabbit oocytes were characterized by a distinct nuclear membrane, a compact nucleolus or nucleoli and highly condensed bivalents in nucleoplasm, mainly around the nucleolus. After the disappearance of the nuclear enve- lope, late diakinesis chromatin was visible in the form of one or several orcein-positive lumps. The frequency of GVBD in Table I and II was compared on the basis of chi-square analysis.

\section{RESULTS}

First, the time-sequence of germinal vesicle breakdown (GVBD) under the described conditions was tested. While after $2 \mathrm{~h}$ of culture all cumulus-enclosed oocytes remained at the GV stage, after 3 and $4 \mathrm{~h}$ of culture $66 \%$ and $97 \%$ of oocytes respectively reached the late diakinesis stage (Table I). Accordingly, the 4-h cul-

Table I. The effect of $\alpha$-amanitin on resumption of meiosis in rabbit cumulus-enclosed and cumulusfree oocytes.

\begin{tabular}{|c|c|c|c|c|c|c|c|}
\hline \multirow{2}{*}{$\begin{array}{l}\text { Typea } \\
\text { of } \\
\text { oocyte }\end{array}$} & \multirow{2}{*}{$\begin{array}{l}\text { Time of } \\
\text { culture in } \\
\text { control } \\
\text { medium }(h)\end{array}$} & \multirow{2}{*}{$\begin{array}{c}\text { Time of } \\
\text { culture in } \\
\alpha \text {-amanitin } \\
\text { (h) }\end{array}$} & \multirow{2}{*}{$\begin{array}{l}\text { Time of } \\
\text { culture in } \\
\text { control } \\
\text { medium }(h)\end{array}$} & \multirow{2}{*}{$\begin{array}{c}\text { No. } \\
\text { of } \\
\text { oocytes }\end{array}$} & \multicolumn{2}{|c|}{ Nuclear configuration } & $\%$ \\
\hline & & & & & GV & $\angle D$ & $G V B D$ \\
\hline
\end{tabular}

\begin{tabular}{|c|c|c|c|c|c|c|c|}
\hline & & & 2 & 27 & 27 & & 0 \\
\hline & & & 3 & 30 & 10 & 20 & 66.6 \\
\hline & & & 4 & 34 & 1 & 33 & $97.0 \cdot d$ \\
\hline $\mathrm{C}_{+}$ & & 4 & & 39 & 37 & 2 & $5.1 \cdot+$ \\
\hline & & 4 & 4 & 42 & 15 & 27 & 64.2 \\
\hline & 1 & 3 & & 38 & 34 & 4 & 10.5 \\
\hline & 2 & 2 & & 36 & 9 & 27 & $75.0+$ \\
\hline & & & 4 & 32 & 1 & 31 & 96.8 \\
\hline $\mathrm{C}-$ & & 4 & & 42 & 4 & 38 & 90.40 \\
\hline & $\mathrm{GR}^{\mathrm{c}}$ & 4 & & 35 & 8 & 27 & 77.10 \\
\hline
\end{tabular}

\footnotetext{
a $\mathrm{C}+$ cumulus-enclosed oocytes; $\mathrm{C}$ - denuded oocytes.

b The culture medium was supplemented with $100 \mu \mathrm{g} \alpha$-amanitin $/ \mathrm{ml}$.

c Denuded oocytes were co-cultured with $1 \times 10^{6}$ parietal granulosa cells(GR)/ml

d - These values are significantly different $(\alpha=0.001)$.

$++$

o 0 These values are not significantly different.
} 

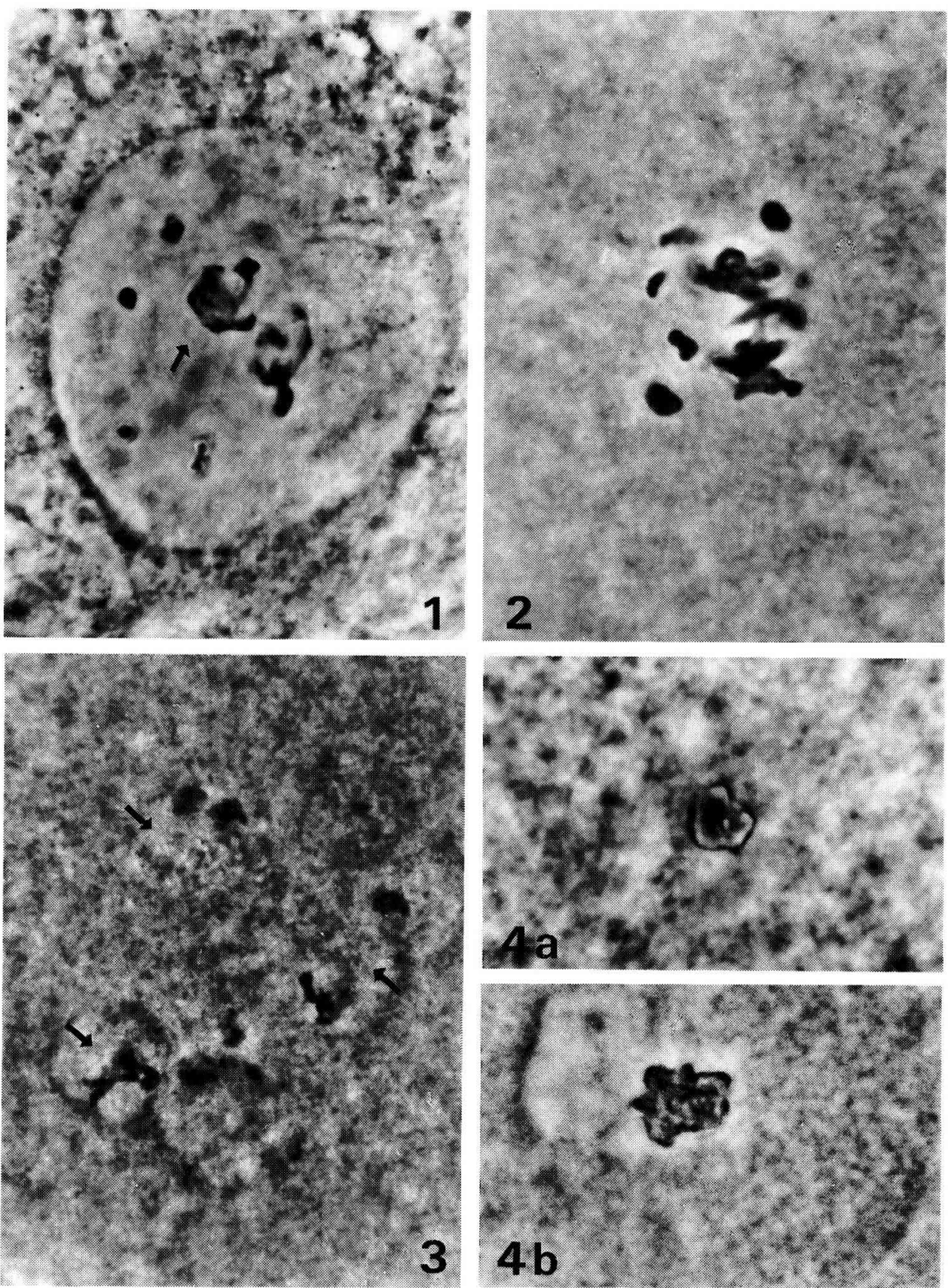
ture interval was applied in all following experiments.

The sensitivity of rabbit cumulusenclosed oocytes to $\alpha$-amanitin was tested at concentrations of 10,50 and $100 \mu \mathrm{g} / \mathrm{ml}$. As the experiment proved, only the highest concentration fully inhibited GVBD $(33,21$ and $3 \%$, respectively) (Fig. 1). The inhibition was reversible after subsequent culture (4 h) in the control medium (64\%) (Fig. 2). A greater reversibility of the $\alpha$ amanitin block was observed on removal of cumulus cells after incubation in the drug $(82 \%$, data not shown). The inhibitory effect was greatly reduced when $\alpha$ amanitin was added $2 \mathrm{~h}$ after the onset of culture (75\% of GVBD).

Surprisingly, $\alpha$-amanitin did not exert any inhibitory effect on denuded oocytes (Table I). The rate of GVBD in the control and $\alpha$-amanitin-supplemented medium was quite comparable (96 and $90 \%$, respectively). The culture of denuded oocytes with $\alpha$-amanitin in a suspension of granulosa cells did not significantly reduce GVBD (77\%); however, the GVBD sequence was slower. Oocytes with remains of nucleoplasm and highly condensed bivalents were included in the GV category (about 10\%) (Fig. 3).

The first series of experiments documented the high sensitivity of rabbit cumulus-enclosed oocytes to 1,5 and $10 \mu \mathrm{g}$ of cycloheximide/ml ( $<5 \%$ of GVBD). Accordingly, $5 \mu \mathrm{g}$ cycloheximide $/ \mathrm{ml}$ was applied in all further experiments (see Table II). The inhibitory effect of cycloheximide was fully reversible since more than $86 \%$ of oocytes reached late diakinesis, when cycloheximide treatment was followed by $4 \mathrm{~h}$ culture in the control medium. When cycloheximide was added $2 \mathrm{~h}$ after initiation of culture, only $8.8 \%$ of oocytes did not keep GV. However, the addition of cycloheximide 2.5 and $3 \mathrm{~h}$ after explantation resulted in GVBD in as many as $65 \%$ and $89 \%$ of oocytes, respectively.

In a similar manner to $\alpha$-amanitin, the inhibitory action of cycloheximide on rabbit oocytes maturation was dependent upon the presence of intact cumulus. GVBD occurred in $85 \%$ of denuded oocytes in cycloheximide supplemented medium (Table II). Co-culture of denuded oocytes with the granulosa cells did not substitute for intact cumulus, since more than $75 \%$ of GVs were broken down after $4 \mathrm{~h}$ of culture (Fig. 4a, b).

\section{DISCUSSION}

Under our culture conditions, GVBD occurred in $66 \%$ and $97 \%$ of rabbit cumulusenclosed oocytes after 3 and $4 \mathrm{~h}$ of culture, respectively. Thibault (1972) observed a somewhat faster maturation sequence, since all oocytes reached prometaphase or metaphase I after $3.5 \mathrm{~h}$ of culture.

Fig. 1. The germinal vesicle of a rabbit oocyte cultured as oocyte cumulus complex in $\alpha$-amanitinsupplemented medium for $4 \mathrm{~h}$. The highly condensed bivalents are localized mainly around the nucleolus (arrow). $\times 800$.

Fig. 2. An oocyte in the late diakinesis stage. The 4 - $\mathrm{h} \alpha$-amanitin treatment was followed by $4 \mathrm{~h}$ culture in the control medium. $\times 1000$.

Fig. 3. The rest of the germinal vesicle of an oocyte cultured for $4 \mathrm{~h}$ in a suspension of granulosa cells in $\alpha$-amanitin-supplemented medium. The highly condensed bivalents are still localized in an area of the GV and are surrounded by nucleoplasm (arrow) $\times 800$.

Fig. 4. a) A denuded oocyte cultured $4 \mathrm{~h}$ in cycloheximide supplemented medium. The highly condensed bivalents clumped in a orcein-positive spot. $x 800$. b) The same phenomenon was observed when the cycloheximide medium was supplemented with granulosa cells. $\times 800$. 
Table II. The effect of cycloheximide on resumption of meiosis of rabbit cumulus-enclosed and denuded oocytes.

\begin{tabular}{|c|c|c|c|c|c|c|c|c|}
\hline \multirow{2}{*}{$\begin{array}{l}\text { Typea } \\
\text { of } \\
\text { oocyte }\end{array}$} & \multirow{2}{*}{$\begin{array}{l}\text { Time of } \\
\text { culture in } \\
\text { control } \\
\text { medium }(h)\end{array}$} & \multirow{2}{*}{\multicolumn{2}{|c|}{$\begin{array}{c}\text { Time of } \\
\text { culture in } \\
\text { cycloheximideb } \\
\text { (h) }\end{array}$}} & \multirow{2}{*}{$\begin{array}{c}\text { Time of } \\
\text { culture in } \\
\text { control } \\
\text { medium }(h)\end{array}$} & \multirow{2}{*}{$\begin{array}{c}\text { No. } \\
\text { of } \\
\text { oocytes }\end{array}$} & \multicolumn{2}{|c|}{ Nuclear configuration } & \multirow{2}{*}{$\begin{array}{c}\% \\
\text { GVBD }\end{array}$} \\
\hline & & & & & & GV & $L D$ & \\
\hline \multirow{6}{*}{$\mathrm{C}+$} & & & & 4 & 28 & 1 & 27 & $96.4 \cdot d$ \\
\hline & & & 4 & & 32 & 31 & 1 & $3.2 \cdot+$ \\
\hline & & & 4 & 4 & 30 & 4 & 26 & 86.6 \\
\hline & 2 & & 2 & & 34 & 31 & 3 & 8.8 \\
\hline & 2.5 & & 1.5 & & 38 & 13 & 25 & 65.7 \\
\hline & 3 & & 1 & & 39 & 4 & 35 & $89.7+$ \\
\hline \multirow{3}{*}{$\mathrm{C}-$} & & & & 4 & 34 & 2 & 32 & 94.1 \\
\hline & & & 4 & & 40 & 6 & 34 & $85.0 \circ$ \\
\hline & & $\mathrm{GR}^{\mathrm{c}}$ & 4 & & 26 & 6 & 20 & $76.9 \circ$ \\
\hline
\end{tabular}

a $\mathrm{C}+$ cumulus-enclosed; $\mathrm{C}$ - denuded oocytes.

b The culture medium was supplemented with $5 \mu \mathrm{g}$ cycloheximide/ml.

c Denuded oocytes were co-cultured with $1 \times 10^{6}$ parietal granulosa cells(GR)/ml.

d - These values are significantly different $(\alpha=0.001)$.

$++$

o o These values are not significantly different.

Autoradiographic experiments with $3 \mathrm{H}-$ uridine incorporation in cumulus oocyte complexes in $\alpha$-amanitin supplemented media (Kanka \& Motlik, unpublished results) confirmed the conclusion of Kidder et al. (1985) that $\alpha$-amanitin in concentrations $<100 \mu \mathrm{g} / \mathrm{ml}$ did not bring about a quick interruption of heterogeneous nuclear RNA synthesis. As we demonstrate here, only this particular concentration $(100 \mu \mathrm{g} / \mathrm{ml})$ fully inhibited GVBD in cumulus-enclosed rabbit oocytes. In the sheep and the cow respectively, only $71 \%$ and $62 \%$ of cumulus-enclosed oocytes remained in the GV stage in the presence of $10 \mu \mathrm{g} / \mathrm{ml}$ of $\alpha$-amanitin throughout culture (Osborn \& Moor, 1983; Hunter \& Moor,
1987). This inhibitory effect was substantially reduced by delaying the addition of $\alpha$-amanitin. While 1 and $2 \mathrm{~h}$ of preincubation without inhibitor permitted GVBD in $60 \%$ and $83 \%$ of ovine oocytes respectively (Osborn \& Moor, 1983), 10 and $75 \%$ of rabbit oocytes attained late diakinesis with the same scheme (the present results). Again, this discrepancy could be explained by using different concentrations of the inhibitor. Probably $10 \mu \mathrm{g} / \mathrm{ml}$ of $\alpha$-amanitin was unable to effect a sufficiently rapid inhibition of hnRNA synthesis.

The inhibitory effect of $\alpha$-amanitin in all examined species (the sheep, the cow and the rabbit) was reversible. Moreover, $70 \%$ 
of denuded sheep oocytes (Osborn \& Moor, 1983) and $90 \%$ of rabbit oocytes (present results) showed normal late diakinesis or metaphase $I$ in $\alpha$-amanitinsupplemented media. All these data argue against the possibility that the inhibition of maturation by $\alpha$-amanitin is due to a secondary effect. Furthermore, the present data support a previous conclusion by Osborn \& Moor (1983) that an early transcriptional event is required for the resumption of meiosis in mammalian oocytes. In the present study, we unequivocally demonstrate that this necessary transcriptional event occurs within the cumulus cells.When in some cases (not reported in the Results) only corona cells were left around oocytes, GVBD occurred in the presence of $\alpha$-amanitin. This shows that the drug does not act on the oocytes even in a case where there should be no doubt about its penetration (see Osborn \& Moor, 1983 ), but that an intact cumulus is necessary for inhibition to occur.

The evidence obtained in the present study strongly supports the view that the translation of newly synthesized mRNAs results in the synthesis of proteins which may participate in the resumption of meiosis (Moor \& Crosby, 1986). Indeed, GVBD was absolutely and reversibly inhibited by cycloheximide in cumulus-enclosed rabbit oocytes. This block was evident even after $2 \mathrm{~h}$ of preincubation in the control medium. However, the addition of the inhibitor 2.5 and $3 \mathrm{~h}$ after explantation allowed 65 and $89 \%$ oocytes to undergo GVBD, respectively. These results elucidate the effect of RNA and protein synthesis on the timing of meiosis resumption in cumulus-enclosed rabbit oocytes. In fact, an $\alpha$-amanitinsusceptible period is followed by a cycloheximide-sensitive period for the resumption of meiosis. Both events are localized in the cumulus cells, since cycloheximide did not significantly influence maturation rate in rabbit denuded oocytes, although this drug is able to act on cumulus-free oocytes (at least in other species; see Introduction). It should also be stressed that the resumption of meiosis in LH-stimulated explanted antral rat follicles requires an active protein synthesis (Lindner et al., 1974).

Rabbit cumulus-enclosed oocytes mature effectively in vitro in a suspension of homologous granulosa cells (Motlik \& Fulka, 1981). Co-culture of the granulosa cells with denuded rabbit oocytes in $\alpha$-amanitin or cycloheximide-supplemented media did not substitute the intact cumulus. This implies that the maintenance of oocytecumulus cell contact is necessary for the inhibitory action of $\alpha$-amanitin and cycloheximide on the resumption of meiosis in the rabbit. The contact is secured by numerous gap junctions between the granulosa cells, the corona radiata cells and the oocyte (Albertini \& Anderson, 1974; Szöllösi et al., 1978). Intrafollicularly, these junctions form a kind of functional syncitium which is a morphological prerequisite for the maintenance of the oocytes in dictyate stage in Graafian follicles before $\mathrm{LH}$ surge (Moor et al.,1980). Since the mitotic index of granula cells is $<1 \%$, fully grown mammalian oocytes are supplied with "interphase factors" described in somatic cells (Rao \& Adlakha, 1985). These interphase-specific substances might be a negative signal passing from granulosa cells to the oocyte and preventing activation of maturation-promoting factor (MPF) (Adlakha et al., 1983; Fulka Jr. et al., 1985). The present results obtained under in vitro conditions strongly suggest that metabolic changes induced in parietal and cumulus granulosa cells, either in vivo by $\mathrm{LH}$ or in vitro by explantation are key events for the resumption of meiosis in mammals and initiation of a metabolic pathway leading to MPF activation in the 
cytoplasm of oocytes (Kubelka et al., 1988).

\section{ACKNOWLEDGMENTS}

The authors are indebted to Dr.P.Creighton for editing the text, Mrs.Jirina Zelenkova and Jana Schwarzova for excellent technical assistance and typing of the manuscript.

\section{REFERENCES}

Adlakha R.C., Sahasrabudhe C.G., Wright D.A. \& Rao P.N.(1983) Evidence for the presence of inhibitors of mitotic factors during $\mathrm{G} 1$ period in mammalian cells. J. Cell Biol. 97, 1707-1713

Albertini D.F. \& Anderson E. (1974) The appearance and structure of intercellular connections during the ontogeny of the rabbit ovarian follicle with particular reference to gap junction. J. Cell Biol. 63, 234-250

Bae I.H.\& Foote R.H. (1975a) Carbohydrate and amino and requirements and ammonia production of rabbit follicular oocytes matured in vitro. Exp. Cell Res. 91, 113-118

Bae I.H.\& Foote R.H.(1975b) Effects of hormones on the maturation of rabbit oocytes recovered follicles of various size. J. Reprod. Fertil. $42,357-360$

Bae I.H. \& Foote R.H. (1980) Maturation of rabbit follicular oocytes in a defined medium of varied osmolarity. J. Reprod. Fertil. 59, 11-13

Crozet N. \& Szöllösi D. (1980) Effects of actinomycin $D$ and $\alpha$-amanitin on the nuclear ultrastructure of mouse oocyte. Biol. Cell 38, 163170

Ekholm C. \& Magnusson C. (1979) Rat oocyte maturation : effects of protein synthesis inhibitors. Biol. Reprod. 21, 1287-1293

Fulka J.Jr., Motlík J., Fulka J. \& Crozet N.(1985) Inhibition of nuclear maturation in fully grown porcine and mouse oocytes after their fusion with growing porcine oocytes. J. Exp. Zool. 235, 255-259
Fulka J. Jr., Motlik J., Fulka J.\& Jilek F.(1986) Effect of cycloheximide on nuclear maturation of pig and mouse oocytes. J. Reprod. Fertil. 77, 281-285

Hunter A.G. \& Moor R.M. (1987) Stagedependent effects of inhibiting ribonucleic acids and protein synthesis on meiotic maturation of bovine oocytes in vitro. J. Dairy Sci. 70, 16461651

Kidder G.M., Green F.\& McLachlin J.R.(1985) On the use of $\alpha$-amanitin as a transcriptional blocking agent in mouse embryos : a cautionary note. J. Exp. Zool. 233, 155-159

Kubelka M., Motlik J., Fulka J.Jr.,Prochazka R.,Rimkevicova Z.\& Fulka J.(1988) Time sequence of germinal vesicle breakdown in pig oocytes after cycloheximide and p-aminobenzamidine block.Gamete Res. 19, 423-431

Lindner H.R.,Tsafriri A., Lieberman M.E., Zor U., Koch Y., Bauminger S. \& Barnea A. (1974) Gonadotrophin action on cultured graafian follicles : induction of maturation division of the mammalian oocyte and differentiation of the luteal cells. Recent Prog. Horm. Res. 30, 79-138

Magnusson C., Le Maire W.J. \& Hillensjö $T$. (1981) Stimulation by hCG in vivo of oxygen consumption by rabbit oocytes in vitro. J. Reprod. Fertil. 61, 185-188

Moor R.M. \& Crosby I.M.(1986) Protein requirement for germinal vesicle breakdown in ovine oocytes .J. Embryol. Exp. Morphol. 94, 207-220

Moor R.M., Smith M.W. \& Dawson M.C. (1980) Measurement of inter-cellular coupling between oocytes and cumulus cells using intra-cellular markers. Exp. Cell Res. 126, 15-29

Motlik J. \& Fulka J. (1981) Fertilization of rabbit oocytes cocultured with granulosa cells. J. Reprod. Fertil. 63, 425-429

Osborn J.C. \& Moor R.M.(1983) Time-dependent effects of $\alpha$-amanitin on nuclear maturation and protein synthesis in mammalian oocytes. $J$. Embryol. Exp. Morphol. 73, 317-338

Pincus G. \& Enzmann E.V.(1935) The comparative behavior of mammalian eggs in vivo and in vitro.l.The activation of ovarian eggs. J. Exp. Med. 62, 665-675

Rao P.N.\& Adlakha R.C.(1985) Chromosome condensation and decondensation factors in the life cycle of eukaryotic cells, 45-69. In : Media- 
tors in Cell growth and Differentiation (R.J. Ford \& A.L. Maizel, eds), Raven Press, New York

Schultz R.M. \& Wassarman P.M.(1977) Biochemical studies of mammalian oogenesis; protein synthesis during oocyte growth and meiotic maturation in the mouse.J. Cell Sci. 24, 167-194

Sirard M.A. \& First N.L. (1988) In vitro inhibition of oocyte nuclear maturation in the bovine. Biol. Reprod. 39, 229-234

Smith D.H., Tyler J.P.P. \& Erickson G.F. (1978) Effects of medium composition and progesterone on maturation in vitro of rabbit oocytes from Graffian follicles of different sizes. J. Reprod. Fertil.54, 393-410
Szöllösi D., Gérard M., Ménézo Y. \& Thibault C. (1978) Permeability of ovarian follicle; corona cell-oocyte relationship in mammals. Ann. Biol. Anim. Biochim. Biophys. 18, 511-521

Thibault C. (1972) Final stages of mammalian oocyte maturation, 392-411. In : Oogenesis (J.D. Biggers \& A.W. Schuetz, eds), Univ.Parks Press, Baltimore

Thibault C. \& Gérard M. (1973) Cytoplasmic and nuclear maturation of rabbit oocytes in vitro. Ann. Biol. Anim. Biochim. Biophys. 13, 145-155

Thibault C., Szöllösi D. \& Gérard M.(1987) Mammalian oocyte maturation. Reprod. Nutr. Dévelop. $27,865-896$ 